\title{
EFFECT ON THE CHEMICAL COMPOSITION OF THE BODY OF WORKER BEES (APIS MELLIFERA L.) FED WITH STIMULATING PRODUCTS
}

\author{
Rositsa Shumkova $^{1}$, Ivanka Zhelyazkova² ${ }^{2}$ Svilen Lazarov², Ralitsa Balkanska ${ }^{3}$ \\ ${ }^{I}$ Agricultural and Stockbreeding Experimental Station, \\ Smolyan, 4700 Bulgaria \\ ${ }^{2}$ Department of Animal Science - Non Ruminants and Other Animals, Faculty of Agriculture, \\ Trakia University, Stara Zagora, 6000 Bulgaria \\ ${ }^{3}$ Institute of Animal Science, Department of Special Branches - Bees, \\ Kostinbrod, 2232 Bulgaria \\ rositsa6z@abv.bg
}

\begin{abstract}
The purpose of the work was to study the impact of stimulating products in the spring and autumn feeding of the bee families. More specifically, on the chemical composition of the worker bees body's of Apis mellifera L. The study was conducted in the beekeeping seasons (spring and autumn) in 2011 and 2012 at the experimental apiary of the Agricultural and Stockbreeding Experimental Station (ASES) - Smolyan, and at the apiary of beekeeping farm "Mitevi" in Smolyan. The bee families were fed with the products "Vita Feed Gold" (includes natural extract of beet and molasses in distilled water), "Apidas" (consisting of plant extracts), "Oligofosi" (contains amino acids) and "Anolyte-7" (electrochemically activated aqueous solution). Moisture (\%), crude protein (\%), crude fats (\%) and ash contents (\%) in the bee body are defined. During the spring the higher contents of crude protein and fat in the bee body of bee families received stimulating products "Vita Feed Gold" (in the apiary of ASES - Smolyan), "Apidas" and "Oligofosi" (apiary beekeeping farm "Mitevi") were found in comparison to the bee body of the bees from the control group. At the end of the beekeeping season the higher (relative to the control group bee families) are the protein and fat contents in the bee body which are received with the food "Apidas" and "Oligofosi". The use of activated water "Anolyte-7" as a sugar solvent leads to accumulation of protein and fat reserves in the bee body in the autumn feeding of the bee colonies. No significant differences in the ash contents of the bee body were found, irrespective of the stimulatory product and the season.
\end{abstract}

Key words: bee feeding; bee family; "Vita Feed Gold"; "Anolyte-7"; "Apidas"; "Oligofosi"

\section{ВЛИЈАНИЕ ВРЗ ХЕМИСКИОТ СОСТАВ НА ТЕЛОТО НА ПЧЕЛИТЕ РАБОТНИЧКИ (APIS MELLIFERA L.) ХРАНЕТИ СО СТИМУЛИРАЧКИ ПРОИЗВОДИ}

Целта на ова испитување беше да се проучи влијанието на стимулирачките производи во пролетното и есенското хранење на пчелните семејства. Поконкретно, на хемискиот состав на телото на пчелите работнички од Apis mellifera L. Студијата беше спроведена во пчелните сезони (пролет и есен) во 2011 и 2012 година во експерименталната пчеларница на Земјоделската и сточарската експериментална станица (ASES) во Смолјан и во пчеларницата „Митеви“ во Смолјан. Пчелните семејства беа хранети со производите „Vita Feed Gold“ (природен екстракт од репка и меласа во дестилирана вода), „Арidas“ (се состои од растителни екстракти), „Oligofosi“ (содржи аминокиселини) и „Anolyte-7““ (електрохемиски активиран воден раствор). Определени се влагата $(\%)$, суровите протеини (\%), суровите масти (\%) и содржината на пепел (\%) во телото на пчелите. Во текот на пролетта беше забележана повисока содржина на сурови протеини и масти во телото на пчелите од пчелните семејства кои добивале стимулирачки производи „Vita Feed Gold“ (во пчеларницата на ASES во Смолјан), „Apidas“ и „Oligofosi““ (пчеларска фарма „Митеви“) во споредба со телото на пчелите од контролната група. На крајот на пчелната сезона, повисока (во однос на контролната група пчелни семејства) беше содржината на протеини и масти во телото на пчелите кои со храната добивале „Apidas“ и „Oligofosi“. Употребата на активирана вода „Аnolyte-7“ како шеќерен раствор довела до акумулација на резерви на протеини и масти во телото на пчелите при есенското хранење на пчелните колонии. Не се забележани значајни разлики во содржината на пепел во телото на пчелите, без оглед на стимулирачкиот производ и сезоната.

Клучни зборови: хранење на пчели, пчелно семејство, „Vita Feed Gold“, „Anolyte-7““, „Apidas“, „Oligofosi“ 


\section{INTRODUCTION}

For their normal living honey bees require complete nutrition with enough protein, fats, carbohydrates, vitamins and minerals. The honey bees receive all necessary nutrients with the natural foods (nectar, bee honey, honeydew, bee pollen, royal jelly). The bee pollen contains all necessary ingredients for the growth and development of the bee, for the proper function of the wax and the hypopharyngeal glands and the syntesis of enzymes and nutrients. These ingredients are proteins, amino acids, fats, carbohydrates, vitamins, minerals, enzymes and hormones (Crailsheim, 1990; Lebedev, 1991).

The honey bees collect, transport and store their food on their own. For the normal development of the bee families in the crisis periods some additional feeding is needed. Most commonly, bee honey, different concentration of sugar solution and inverted sugar solution are used.

In the recent years, in the Bulgarian beekeeping, alternative products have been tested in the spring and autumn feeding of the bee families based on biologically active substances from different plants: essential oils, plant extracts and organic acids. The spring activities in the raising and the feeding of the bee families are connected to maximum amount of bees and cupped bee brood in the preparation for the main bee pasture (Nenchev, 2010).

For the climactic conditions between the middle of August and the end of October in Bulgaria, the bee families should have a sufficient amount of physiologically young bees which are hatched in the autumn. They should have a well-developed fat body to survive successfully during the winter (Nenchev et al., 2002; Bijev 2005).

The purpose of the work was to study the impact of stimulating products in the spring and autumn feeding of the bee families. More specifically, on the chemical composition of the worker bees body's of Apis mellifera $\mathrm{L}$.

\section{MATERIALS AND METHODS}

\section{Materials}

The experiments included the local bee colonies of Apis mellifera $\mathrm{L}$. settled in Langstrot-Rut (multihull) hives.

For feeding the bee families the products "Vita Feed Gold", "Apidas", "Oligofosi" and "Anolyte-7" were used.
"Vita Feed Gold" is a liquid concentrated food for bees made from natural extracts of beet and molasses in distilled water. Its purpose is to stimulate the growth and the development of the bee colonies. It has scientifically proven effect to reduce the number of spores of Nosema apis. It has a marked positive effect in the treatment of diarrhea. It can be used any time of the year but the best effect is achieved if it is applied in spring or autumn on the weakened bee families. For stimulation of the bee families a solution of $10 \mathrm{ml}$ of "Vita Feed Gold" and $990 \mathrm{ml}$ of sugar solution (1:1) is prepared.

"Apidas" is a Georgian preparation of herbal extracts. It is a dark liquid with unpleasant odor. It is easily digested by the bees with sugar solution $1: 1$. The product was applied in a single dose of 5 $\mathrm{ml}$ to $500 \mathrm{ml}$ of sugar solution per bee family.

"Oligofosi" is a Georgian preparation based on amino acids. It is a dark liquid with unpleasant odor. It is easily digested by the bees with sugar solution $1: 1$. It was applied in a single dose of $5 \mathrm{ml}$ to 500 $\mathrm{ml}$ of sugar solution per bee family.

"Anolyte-7" is a colorless liquid with characteristic odor of oxidants. The active principles in the anolyte are metastable mixture chlorine-oxygenous and peroxide compounds which in the period of its relaxation change their relative concentrations. After this period the anolyte returns to its original condition - a low-mineralized aqueous solution.

\section{Methods}

\subsection{Research 2011}

The spring stimulating feeding was conducted during the period 8.4.-6.6.2011. The experiment was conducted at two apiaries: ASES apiary and Mitevi's bee farm in Smolyan. The autumn feeding is carried out from 1. 8. to 28. 09. 2011 at ASES apiary.

2.1.1. Bee family groups: A total of 6 groups were formed -2 control groups (for each apiary per one) and 4 experimental with 5 bee families per group, equal in quantity of bees (strength), brood and food supplies. The autumn feeding was conducted at one apiary with 5 groups of bee families (1 control and 4 experimental).

The feeding of the colony was carried out by the following scheme:

- Control group - feeding with sugar solution ( $1: 1)$ without additives; 
- Experimental group - feeding with the addition of "Vita Feed Gold" at a dose of $10 \mathrm{ml} / \mathrm{l}$ sugar solution $(1: 1)$;

- Experimental group - nourishing by adding "Apidas" in a single dose of $5 \mathrm{ml}$ to $500 \mathrm{ml}$ of sugar solution;

- Experimental group - nourishing by adding "Oligofosi" in a single dose of $5 \mathrm{ml}$ to $500 \mathrm{ml}$ of sugar solution;

- Experimental group - feeding with "Anolyte$7 "$. The solution is prepared from sucrose and anolyte $(1: 1)$. For each bee colony a total of 5 liters sugar solution is provided in the feeders of the hives in $500 \mathrm{ml}$ at intervals of $2-3$ days.

\subsection{Research 2012}

2.2.1. Bee family groups: For each experimental period 1 control and 4 experimental groups with 5 bee families were formed.

2.2.2. Feeding of the bee families: The feeding of the bee families was done under the same scheme and with the same amount of food as in 2011.

\subsection{Determination of the worker bees body's chemical composition}

The bee body samples for chemical analysis were taken at the end of the spring and autumn experimental periods after the end of the stimulating feeding.

The samples with worker bees were collected from each bee family and from different honeycombs. The samples were stored in a freezer $\left(-20^{\circ} \mathrm{C}\right)$ until the analysis.

The analyses for the chemical composition of the worker bees body' were carried out at the Research Laboratory of the Faculty of Agriculture at Trakia University, Stara Zagora. The following parameters were determined:

- Moisture (\%) and ash (\%) - weight analysis (gravimetry) according to BDS - SR ISO 5984;

- Protein (\%) - Keldahl method, BDS - SR ISO 5983;

- Fats (\%) - Soxhlet extraction method, BDS SR ISO 6492.

The obtained results were processed statistically using Excel.

\section{RESULTS AND DISCUSSION}

\section{Chemical composition of the worker bees body's in 2011}

\section{Spring period}

The chemical composition of the worker bees body's in spring 2011 is shown in Table 1 . The data show that the dry matter contents for the bee samples from ASES apiary range from $31.25 \pm 0.63 \%$ ("Vita Feed Gold") to $36.95 \pm 0.80 \%$ (control group). Similar to the control group are the dry matter values of the bees fed with "Anolit-7" (Table 1).

From the results obtained (Table 1), the crude protein contents from the control group and the bee families fed with "Anolyte-7" and "Vita Feed Gold" varied in a narrow range from $45.52 \pm 0.35 \%$ to $51.71 \pm 0.33 \%$. The statistically significant differences are at $\mathrm{p} \leq 0.05$.

The mean values for the crude fats in the bee body were similar to those of the control group and the group receiving "Vita Feed Gold" (5.03 $\pm 0.15 \%$ and $5.86 \pm 0.17 \%$, respectively). They are relatively low in the bees fed with "Anolyte-7" (3.86 \pm $0.18 \%)$. The statistical difference $(\mathrm{p} \leq 0.01)$ between the groups was as follow: Control group "Anolyte-7", Control group - "Vita Feed Gold", "Anolyte-7" - "Vita Feed Gold".

The comparative analysis of the data (Table 1) shows that the bee samples from families stimulating with "Vita Feed Gold" (from ASES apiary) differ from the other bee family groups included in the study in terms of crude protein and crude fats. The crude protein and crude fats values in the bee bodies of this group are higher compared to the control group samples.

The minimum dry matter content in the bee families from Mitevi's bee farm was established for the bee samples receiving "Apidas" (29.42 $\pm 1.08 \%)$ and the maximum value for the bees stimulated with "Oligofosi" (36.62 $\pm 0.51 \%)$ (Table 1).

The results obtained show higher crude protein values in the bee body from the experimental groups (fed with "Apidas" and "Oligophosi") versus the control group samples. A maximum value for crude fats was established for bee families receiving "Apidas" with their food $(6.76 \pm 0.06 \%)$. Identical values were determined for the control group and the group stimulating with "Oligofosi" (5.03 $\pm 0.06 \%$ and $5.83 \pm 0.07 \%$, respectively).

Concerning the parameters crude protein and crude fats in the bees body's the significant differences $(p \leq 0.05)$ were found between the control groups - "Apidas" and "Apidas" - "Oligofosi". 
Table 1

Chemical composition of the worker bees body's - spring 2011

\begin{tabular}{|c|c|c|c|c|c|c|}
\hline \multirow{2}{*}{$\begin{array}{l}\text { Parameters } \\
\text { Chemical } \\
\text { composition } \\
\end{array}$} & \multicolumn{5}{|c|}{ Groups } & \multirow[b]{2}{*}{ Significant differences } \\
\hline & $\begin{array}{l}\text { Control } \\
\text { (C) }\end{array}$ & "Anolyte-7" & $\begin{array}{l}\text { "Vita Feed Gold""' } \\
\text { (VFG) }\end{array}$ & "Apidas" & "Oligofosi" & \\
\hline \multicolumn{7}{|c|}{ ASES apiary - Smolyan } \\
\hline Moisture, \% & $63.05 \pm 0.80$ & $64.70 \pm 1.23$ & $68.74 \pm 0.63$ & & & \\
\hline Dry matter, \% & $36.95 \pm 0.80$ & $35.29 \pm 1.23$ & $31.25 \pm 0.63$ & & & \\
\hline $\begin{array}{l}\text { Crude protein, } \\
\%\end{array}$ & $45.52 \pm 0.35$ & $48.31 \pm 0.69$ & $51.73 \pm 0.33$ & & & $\begin{array}{l}\mathrm{C}-\text { "Anolyte-7"*; C - } \\
\text { VFG**; "Anolyte-7" - } \\
\text { VFG** }\end{array}$ \\
\hline Crude fats, $\%$ & $5.03 \pm 0.15$ & $3.86 \pm 0.18$ & $5.86 \pm 0.17$ & & & $\begin{array}{l}\mathrm{C}-\text { "Anolyte-7"*; C - } \\
\text { VFG**; "Anolyte-7" - VFG } \\
* *\end{array}$ \\
\hline Ash, \% & $1.12 \pm 0.02$ & $1.13 \pm 0.03$ & $1.21 \pm 0.01$ & & & NS \\
\hline \multicolumn{7}{|c|}{ Mitevi's bee farm - Smolyan } \\
\hline Moisture, \% & $67.80 \pm 0.78$ & & & $70.57 \pm 1.08$ & $63.37 \pm 0.51$ & \\
\hline Dry matter, $\%$ & $32.19 \pm 0.78$ & & & $29.42 \pm 1.08$ & $36.62 \pm 0.51$ & \\
\hline $\begin{array}{l}\text { Crude protein, } \\
\%\end{array}$ & $51.04 \pm 0.63$ & & & $64.60 \pm 0.92$ & $53.71 \pm 0.28$ & $\begin{array}{l}\mathrm{C} \text { - "Apidas"*; } \\
\text { "Apidas" - "Oligofosi"* }\end{array}$ \\
\hline Crude fats, $\%$ & $5.03 \pm 0.06$ & & & $6.76 \pm 0.06$ & $5.83 \pm 0.07$ & $\begin{array}{l}\text { C - "Apidas"*; } \\
\text { "Apidas" - "Oligofosi"* }\end{array}$ \\
\hline Ash, $\%$ & $1.34 \pm 0.05$ & & & $1.18 \pm 0.06$ & $1.25 \pm 0.03$ & NS \\
\hline
\end{tabular}

The data from Table 1 show comparable values for the ash contents of the bees body's for the both apiaries - ASES apiary from $1.12 \pm 0.02 \%$ to $1.21 \pm 0.01 \%$ and for the bee samples from Mitevi's bee farm - from $1.18 \pm 0.06 \%$ to $1.34 \pm 0.05 \%$. The differences for the ash contents between the groups in the two apiaries are not significant.

Based on the aggregated data for the both apiaries, high contents of crude protein and crude fats can be commented on the bee samples from families receiving "Vita Feed Gold" and "Apidas" compared to the control groups.

\section{Autumn period}

The chemical composition of worker bees during the autumn experiment is shown in Table 2.

The results obtained show that comparable values for the moisture and dry matter have been found for the all bee family groups.

Table 2 shows that the bees receiving sugar solution and "Anolyte-7" have the highest crude protein values. Similar to the maximum value were re- ported for the bees stimulating with "Apidas". For the bee samples fed with "Vita Feed Gold" the minimum value was reported. The differences between the groups "Anolit-7" - VFG and VFG - "Adidas" are statistically significant at $\mathrm{p} \leq 0.05$.

The lowest crude fats values in the bee body were obtained from bees fed with "Apidas" and "Oligofosi" with the sugar solution $4.78 \pm 0.16 \%$ and $4.68 \pm 0.10 \%$, respectively. The maximum value was reported in the bee families receiving "Anolyte7" $(5.52 \pm 0.12 \%)$. The differences between the groups "Anolit-7" - "Apidas" and "Anolyte-7" "Oligofosi" are statistically significant at $\mathrm{p} \leq 0.05$.

The results obtained for the ash content are similar from $1.11 \pm 0.07 \%$ to $1.23 \pm 0.09 \%$ but they are not statistically significant.

The results show that the used of activated water "Anolyte-7" for the preparation of sugar solution and the autumn feeding of the bee families leads to the accumulation of protein and fat reserves in the worker bee body's. This is especially important for the honey bees hatching at the end of the beekeeping season which will remain to wintering. 
Table 2

Chemical composition of the worker bees body's - autumn 2011

\begin{tabular}{|c|c|c|c|c|c|c|}
\hline \multirow{2}{*}{ Composition } & \multicolumn{5}{|c|}{ Groups } & \multirow{2}{*}{ Significant differences } \\
\hline & Control & "Anolyte-7" & "Vita Feed Gold" (VFG) & "Apidas" & "Oligofosi" & \\
\hline Moisture, \% & $67.50 \pm 0.23$ & $67.40 \pm 0.01$ & $67.10 \pm 0.62$ & $67.78 \pm 0.80$ & $67.83 \pm 0.11$ & \\
\hline Dry matter, \% & $32.50 \pm 0.23$ & $32.59 \pm 0.01$ & $32.89 \pm 0.62$ & $32.21 \pm 0.80$ & $32.16 \pm 0.11$ & \\
\hline Crude protein, $\%$ & $50.63 \pm 0.07$ & $52.55 \pm 1.11$ & $47.33 \pm 0.40$ & $51.22 \pm 0.21$ & $50.57 \pm 0.21$ & $\begin{array}{l}\text { "Anolyte-7" - VFG* } \\
\text { VFG - "Apidas"* }\end{array}$ \\
\hline Crude fats, $\%$ & $5.01 \pm 0.06$ & $5.52 \pm 0.12$ & $5.00 \pm 0.04$ & $4.78 \pm 0.16$ & $4.68 \pm 0.10$ & $\begin{array}{l}\text { "Anolyte-7" - "Apidas"* } \\
\text { "Anolyte-7" - "Oligofosi"* }\end{array}$ \\
\hline Ash, \% & $1.11 \pm 0.07$ & $1.14 \pm 0.07$ & $1.23 \pm 0.08$ & $1.23 \pm 0.09$ & $1.18 \pm 0.06$ & NS \\
\hline
\end{tabular}

$* \mathrm{p} \leq 0.05 ; * * \mathrm{p} \leq 0.01 ; * * * \mathrm{p} \leq 0.001 ; \mathrm{NS}-$ not significant

\section{Chemical composition of the worker bees body's in 2012}

\section{Spring period}

Table 3 presents the data for the chemical composition of the worker bees' body during the spring period 2012. The data show that the dry matter content of the bee samples for the all groups varies in a narrow range from $29.76 \pm 1.98 \%$ ("Oligofosi") to $33.31 \pm 1.11 \%$ ("Apidas").

The results obtained (Table 3 ) show that the reported crude protein content from the bee samples fed with "Apidas" has the highest value (56.20 \pm $1.52 \%)$. The lowest values are on the control group $(34.80 \pm 0.49 \%)$. This value is 1.6 times less than the same value in the bee families receiving "Apidas". The average crude fats values in the bee body were similar to those of the control group and those receiving "Vita Feed Gold" (4.21 $\pm 0.33 \%$ and 4.09 $\pm 0.35 \%$, respectively). The highest result was obtained for the bee families fed with "Oligofosi" $(9.01 \pm 0.60 \%)$. From average to high significant level of the obtained differences was established (Table. 3). Not significant differences were found for the ash contents in the bee body.

Table 3

Chemical composition of the worker bees body's - spring 2012

\begin{tabular}{|c|c|c|c|c|c|c|}
\hline \multirow{2}{*}{ Composition } & \multicolumn{5}{|c|}{ Groups } & \multirow{2}{*}{ Significant differences } \\
\hline & Control & "Anolyte-7" & "Vita Feed Gold" (VFG) & "Apidas" & "Oligofosi" & \\
\hline Moisture, \% & $68.08 \pm 0.71$ & $69.11 \pm 0.62$ & $66.74 \pm 1.02$ & $66.69 \pm 1.11$ & $70.24 \pm 1.98$ & \\
\hline Dry matter, \% & $31.92 \pm 0.71$ & $30.89 \pm 0.62$ & $33.26 \pm 1.02$ & $33.31 \pm 1.11$ & $29.76 \pm 1.98$ & \\
\hline Crude protein, $\%$ & $34.80 \pm 0.49$ & $48.47 \pm 1.00$ & $35.11 \pm 0.25$ & $51.87 \pm 2.97$ & $56.20 \pm 1.52$ & $\begin{array}{l}\text { C-"Anolyte-7"**; } \\
\text { C-"Apidas"**; } \\
\text { C-"Oligofosi"***; } \\
\text { VFG-"Anolyte-7"**; } \\
\text { VFG-"Apidas"**; } \\
\text { VFG-"Oligofosi"*** }\end{array}$ \\
\hline Crude fats, $\%$ & $4.21 \pm 0.33$ & $8.07 \pm 0.99$ & $4.09 \pm 0.35$ & $7.55 \pm 0.67$ & $9.01 \pm 0.60$ & $\begin{array}{l}\text { C-"Anolyte-7"**; } \\
\text { C-"Apidas"**; } \\
\text { C-"Oligofosi"***; } \\
\text { VFG-"Anolyte-7"**; } \\
\text { VFG-"Apidas"**; } \\
\text { VFG-"Oligofosi"*** }\end{array}$ \\
\hline Ash, \% & $1.24 \pm 0.04$ & $1.21 \pm 0.02$ & $1.23 \pm 0.06$ & $1.21 \pm 0.06$ & $1.47 \pm 0.07$ & NS \\
\hline
\end{tabular}

${ }^{*} \mathrm{p} \leq 0.05 ; * * \mathrm{p} \leq 0.01 ; * * * \mathrm{p} \leq 0.001 ; \mathrm{NS}-$ not significant 


\section{Autumn period}

The chemical composition of the worker bees body's in autumn 2012 is presented in Table 4.

The results obtained show that the moisture and dry matter have comparable values. This tendency is repeated in the experiment in 2011.

The highest crude protein value $(36.05 \pm 1.71$ $\%$ ) was received in the bee families fed with the product "Apidas". In the others bee family groups the values obtained are commensurate and they do not depend on the feeding type (Table 4).

In autumn 2012, the lowest crude fats value $(3.84 \pm 0.18 \%)$ was found in the control group samples. The highest value was determined for the bee families fed with "Oligofosi" (4.31 $\pm 0.29 \%)$.

As a conclusion, in autumn 2012 the differences in the results between the bee family groups are not significant.

Based on the results from the two years the high crude protein and crude fats contents can be commented on the bee samples from bee families receiving with their food "Vita Feed Gold", "Apidas" and "Anolyte-7", compared to the control groups. The results obtained for the stimulating impact of "Vita Feed Gold" and "Apidas" are similar to the results of Shumkova and Zhelyazkova (2013, 2015). The authors found positive effects of these preparations on the development of the bee families and degree of development of the hypopharyngeal and thoracic glands of the worker bees.

The positive impact for the application of "Anolyte-7 is complemented by the results of Gurgulova et al. (2011) for enhancing the bee immune defense and honey production. Also, it is useful for the effective control of some bee diseases using electrochemically activated aqueous solutions.

The results for the chemical composition of the worker bees body's give us a reason to comment that the bees from the groups with higher crude protein and crude fats have enough reserve substances. This can guarantee the successful wintering of the bee family.

The results obtained and the results from other studies in our country for plant-based products ("Vita Feed Gold" and "Apidas") and "Anolyte-7" (electrochemically activated aqueous solution) are important for the beekeeping and also for the biological beekeeping (Gurgulova et al., 2006; Nenchev et al., 2006; Gurgulova et al., 2008; Zhelyazkova et al., 2009; Zhelyazkova et al., 2010; Gurgulova et al., 2011; Hristakov, 2012; Hristakov et al., 2013; Shumkova and Zhelyazkova, 2013, 2015). The sudies with focus on the natural products are particularly relevant to the apicultural practice, mainly to obtain ecological bee products.

Table 4

Chemical composition of the worker bees body's - autumn 2012

\begin{tabular}{|c|c|c|c|c|c|c|}
\hline \multirow{2}{*}{ Composition } & \multicolumn{5}{|c|}{ Groups } & \multirow{2}{*}{$\begin{array}{l}\text { Significant } \\
\text { differences }\end{array}$} \\
\hline & Control & "Anolyte-7" & "Vita Feed Gold" VFG & "Apidas" & "Oligofosi" & \\
\hline Moisture, $\%$ & $57.97 \pm 0.90$ & $58.15 \pm 2.01$ & $58.45 \pm 0.72$ & $58.14 \pm 1.24$ & $59.01 \pm 0.34$ & \\
\hline Dry matter, $\%$ & $42.03 \pm 0.90$ & $41.85 \pm 2.01$ & $41.55 \pm 0.72$ & $41.86 \pm 1.24$ & $40.99 \pm 0.34$ & \\
\hline Crude protein, \% & $34.50 \pm 0.72$ & $34.68 \pm 0.72$ & $34.47 \pm 0.68$ & $36.05 \pm 1.71$ & $35.10 \pm 0.19$ & NS \\
\hline Crude fats, $\%$ & $3.84 \pm 0.18$ & $4.21 \pm 0.42$ & $4.05 \pm 0.41$ & $4.29 \pm 0.48$ & $4.31 \pm 0.29$ & NS \\
\hline Ash, $\%$ & $1.29 \pm 0.07$ & $1.41 \pm 0.07$ & $1.30 \pm 0.02$ & $1.31 \pm 0.07$ & $1.31 \pm 0.06$ & NS \\
\hline
\end{tabular}

$* \mathrm{p} \leq 0.05 ; * * \mathrm{p} \leq 0.01 ; * * * \mathrm{p} \leq 0.001 ; \mathrm{NS}-$ not significant

\section{CONCLUSION}

During the two periods (spring and autumn) in 2011, the high crude protein and crude fats were found in the bee samples from families receiving with their food the products "Vita Feed Gold" and "Apidas". In 2012, the stimulating effect of the preparation "Oligofosi" (including amino acids) on the amount of crude protein and crude fats in the bee body was reported.

The results show that the activated water "Anolyte-7" for the preparation of sugar solution and the autumn feeding of the bee families leads to accumulation of protein and fat reserves in the worker bees body'. This is especially important for the bee hatching at the end of beekeeping season. 
During the four seasons no significant differences for the ash content in the bee body were found. The results obtained for the chemical composition of the worker bees body's give us a reason to comment that the bees in the groups with higher crude protein and crude fats contents have a sufficient quantity of reserve substances. This can guarantee the successful wintering of the bee family.

\section{REFERENCES}

[1] Bijev, B: Bee Growing, Sofia, Enyovche [in Bulgarian], . 2005.

[2] Bijev, B., Nenchev, P.: Beekeeping [in Bulgarian], 1990.

[3] Crailsheim, K.: The protein balance on the honey bee worker. Apidologie, 21, 417-429 (1990).

[4] Grancharov, A.: Why the bees die. Apiculture, 12, 2-5. (2007) [in Bulgarian]

[5] Gurgulova, K., Nenchev, P., Zhelyazkova, I., Pavlov, D.: Study of antibacterial and antifungal activity of some essential oils against strains of microorganisms causing diseases in bees and brood. Ecology and Future, 2, 32-36 (2006) [in Bulgarian].

[6] Gurgulova, K., Zhelyazkova, I., Malinova, K., Takova, S.: Study on the biological activity of ECOPHIL-P and GREEN TM to certain infectious agents causing brood diseases. Proceedings of "Tradition and Modernity in Veterinary Medicine". Vita University of Forestry, Sofia, 2008, pp. 306-316 [in Bulgarian]

[7] Gurgulova, K., Karadjov, S., Gogov, Y., Georgieva, T., Yordanov, I.: Application in veterinary medicine of anolytes obtained by electrochemical activation of aqueous solutions of alkaline and alkaline earth salts. Journal of Animal Science, 1, 79-85 (2011) [in Bulgarian].
[8] Hristakov, I., Zhelyazkova, I., Hvarchilkov, V.: Researching the resistance of bees fattened up with additive of extract of Tribulus terrestris L. during wintering. Agricultural Science and Technology, 5, 1, 75-78 (2013).

[9] Hristakov, I.: Effect of the use of Tribulus terrestris L. extract on the development and productivity of the bee families. Dissertation, Stara Zagora, Bulgaria, 2012 [in Bulgarian].

[10] Lebedev, V. I., Bilash, N. G.: Biology of Honey Bee. Agropromizdat, 221-224, 1991 [in Russian].

[11] Nenchev, P., Zhelyazkova, I., Gurgulova, K., Pavlov. D.: Study of acaricide effect of some essential oils added to the food of bees. Ecology and Future, 2, 27-31 (2006) [in Bulgarian].

[12] Nenchev, P., Katsarov, G., Zhelyazkova, I., Topalov, A.: Beekeeping, Dionis, 2002 [in Bulgarian].

[13] Nenchev, P., Zhelyazkova, I.: Beekeeping, Editor Trakia University, 2010 [in Bulgarian].

[14] Shumkova, R., Zhelyazkova, I.: Effect of the feeding of products stimulating the development of bee colonies. $A g$ ricultural Science and Technology, 5, 3: 276-281 (2013).

[15] Shumkova, R., Zhelyazkova, I.: Stimulating feeding and development of hypopharyngeal and thoracic glands of honeybees (Apis mellifera L.). Agricultural Science and Technology, 7, 3:309-312 (2015).

[16] Zhelyazkova, I., Gurgulova, K., Malinova, K., Ali, A. C.: Study of catalytic effect of herbal preparations "Green TM" and "Ecophil-P" on the development of the bee colonies. International Conference, 4-5.VI. 2009, Union of Bulgarian Scientists in Stara Zagora, electronic edition, 2009 [in Bulgarian].

[17] Zhelyazkova, I., Gurgulova, K., Panchev, I., Popova, V.: Effect of the biological stimulating product Apisaniran on the productive parameters of bee colonies, Apimondia First World Conference on Organic Beekeeping, 27-29 August 2010, Sunny Beach, Bulgaria, Book of Abstracts, 2010, p. 82 . 
